\title{
Killing in War: Unasked Questions-Ill-Founded Legitimisation
}

\author{
Albin Eser ${ }^{1,2}$ \\ Published online: 19 July 2017 \\ (C) The Author(s) 2017. This article is an open access publication
}

\begin{abstract}
Killing in war as a matter of course may be inferred from the fact that, as stated by Thomas Hobbes, "all laws are silent in the time of war". Although this traditional lawsuspending power of war has been restricted to a certain degree by modern humanitarian international law, it is still commonly assumed that killing in war, unless and as long as not explicitly forbidden, is per se permitted and thus does not require any further legitimisation. This is in fundamental contrast to a "normal" homicide, which requires special justification to be considered lawful. This commonly unquestioned license to kill, by the mere reason of being at war, is all the more astonishing given that no legal norm can be found that positively and explicitly declares killing in war to be lawful. However, on what ground can such an unwritten privilege be based? How can it be morally justified and sufficiently legitimised? This question shall be pursued in four steps: by, first, asking whether and why killing in war, as long as it does not cross the threshold of a war crime, shall stay outside the rubric of criminal law. After not having found a satisfactory answer, it must, second, be asked whether and to what degree constitutional law could provide empowerments and restrictions of killing in war. As neither will give full answers, third, final refuge may be taken in international law, with particular attention to state sovereignty. Since even on this level, however, killing in war has not yet found convincing legitimisation, fourth, further challenges are to be met.
\end{abstract}

Keywords Killing in war · War crimes · "War paradigm" versus "law enforcement paradigm" . "Rubric of criminal law" versus "rubric of war" . "Enemy criminal law" - Justifications of homicide - Self-defense - Killing of combatants, illegal combatants and civilians · Targeted killing · "War on terror" · Bellum justum · Jus ad bellum and jus in bello: state sovereignty in war · Constitutional empowerments to war $\cdot$ Hague War on Land Order

Albin Eser

a.eser@mpicc.de

1 The Max Planck Institute for Foreign and International Criminal Law, Freiburg, Germany

2 The International Criminal Tribunal for the Former Yugoslavia, The Hague, The Netherlands 


\section{License to Kill in War: A Matter of Course?}

Silent enim leges inter arma. With this phrase, Marcus Tullius Cicero defended the People's tribune Milo's killing of his adversary Clodius in 52 B.C. ${ }^{1}$ Over time this defence has become so commonly recognised that Thomas Hobbes described it as "a fond saying, that all laws are silent in the time of war." 2 Since it has evolved into a frequently quoted truism, it may be a Don Quixote fight against windmills to call the legitimacy of killing in war into question. It seems particularly so when considering that in the meantime warfare has been domesticated by modern humanitarian international law and opened to prosecution when crossing the threshold of a war crime. So, why shouldn't this be sufficient to find killing in war both morally justified and sufficiently legitimised? Why cast doubt on it?

Even though killing in war is restricted and penalised to a certain degree-by outlawing the use of particularly dreadful means and terrible weapons and rejecting disproportionate effects on civilians - why is it considered permissible to kill at all? Shall the mere reason of being at war justify deadly actions? If war is given such a law-suspending power, on what ground can such a privilege be based? This question is not yet answered by simply referring to the limitations of killing in war: to the contrary, to prohibit certain acts of killing implies that otherwise these acts would be allowed. Does this mean that killing in war, unless and as long as not explicitly forbidden, is per se permitted-and thus does not require any further legitimisation? This fundamental question can easily be overlooked if killing in war, while without further ado considered lawful in principle, is scrutinised only with regards to potential restrictions. So, instead of being content with secondary issues of how killing in war may be restricted, the primary question at stake here is why and how killing in war may be legitimised in principle.

To begin, however, I must confess that, just as the mainstream literature, I too was so blinded by the perception of killing in war as a historical and anthropological phenomenon that causing death by military operations should be regarded as a matter of course. As a taboo unavoidably connected with human fatalities, war appeared as a legal vacuum in terms of permitting everything that was not explicitly prohibited. The peculiarity of this assumption can perhaps be best illustrated by comparing the radically different assessment of killing a human being inside and outside of military conflict. Whereas a "normal" homicide, unless specifically justified, is undoubtedly unlawful, killing in war is, in principle, considered lawful-without requiring an individual justification. In addition, not only is the killing of enemies in times of war per se regarded as legitimate but, the greater the death toll, the greater the military decoration. This commonly unquestioned license to kill is all the more astonishing in that, as will be shown below, no legal norm can be found that positively and explicitly declares killing in war to be lawful. Rather, it seems that this practice is based merely on militarily accepted tolerance, without having been fundamentally founded.

This tacit acceptance of killing in war as legitimate may have been tolerable as long as war, somehow declared by one state or state-like power against another, was an easily definable fight. However, in many of today's armed conflicts, this is not the case-the face and methods of war have changed dramatically. Regarding the types and areas in which hostile conflicts may occur, in rising numbers, military activities are not confined to confrontations between states and their regular combatants but may, in a rather more asymmetric manner, be fought between soldiers and stateless combatants, internal

\footnotetext{
${ }^{1}$ M. Tulli Ciceronis Pro T. Annio Milone Oratio (Clarendon Press, 1895), Chap. IV no. 11.

2 Thomas Hobbes, On the Citizen (Cambridge University Press, 1998[1642]), Chap. V, para. 2.
} 
insurgents or other terrorist groups, and transnational networks. With regards to the methods of battle, face-to-face fighting is more and more supplemented, or even substituted, by targeted killing, often performed by drones, thus turning individual confrontations into distant attacks and cyber warfare.

These and similar developments in the concept of war, though, may not be a reason for particular excitement if, in legal terms, it did not matter whether killing human beings occurred in a war or in a different, non-military conflict. This, however, is not the case. For, as stated before, whereas a "normal" homicide requires special justification for being considered lawful, killing in war is privileged, as it is principally regarded as lawful without requiring a particular justification. This fundamental difference between the "war paradigm" and a "law enforcement paradigm" ${ }^{3}$ becomes all the more crucial, and dubious, if there is no clear borderline between murder within the "rubric of criminal law" and a deadly attack within the "rubric of war". ${ }^{4}$ As in the war paradigm military fighters need not fear criminal prosecution, ${ }^{5}$ they themselves as well as the state power they are serving can feel less constrained in their actions. Therefore, it should not be a surprise that, as long as killing does not reach the threshold of a war crime in terms of international criminal law, hostile counterparts will be inclined to call an armed conflict a "war." This explains why George W. Bush's administration was so quick and keen to pronounce the reaction against the 9/11 terrorists and the protection against similar atrocities as the "war on terror", thus avoiding perhaps troublesome ordinary criminal investigations or other constrictions in its means and measures. ${ }^{6}$ However, terrorist groups combatting in a so-called "war" may for their part, too, claim the privilege of fighting in a war, and, thus become exempt from any prosecution for homicide-at least if a transnational element is involved.

In short, call an armed conflict or the prosecution and prevention of terrorist acts a "war" and you are much better off: above ordinary criminal law and less bound to respect human rights guarantees. What makes this assumption even worse is the fact that we increasingly lack clear criteria for what constitutes a war, opening the door for killing while "law falls silent". 7 This danger is further enhanced by the fact that everybody seems to feel empowered to call the employment of military means a "war". "What is war and what is not-war is in fact something that people decide". Although this statement by Michael Walzer ${ }^{8}$ seems merely to address the anthropological and historical accounts that the concept of war depends on cultural settings and the prevailing notions of a given society, it nevertheless reveals that, as a matter of political decision, it lies in the hands of power holders - be it orderly elected governments or self-appointed groups-to call an armed operation a "war."

\footnotetext{
3 Gabriella Blum, and Philip Heymann, "Law and Policy of Targeted Killing," 1 Harvard National Security Journal (2010), pp. 145-170 (155).

4 Robert D. Sloane, "Prologue to a Voluntarist War Convention," 106(3) Michigan Law Review (2007-2007), pp. 443-485 (446).

5 Samuel Issacharoff, and Richard H. Pildes, "Targeted Warfare: Individuating Enemy Responsibility," 88(5) New York University Law Review (2013), pp. 1521-1599 (1545).

6 Ibid., p. 1525. With regards to the martial treatment of terrorists, cf. George P. Fletcher, "On Justice and War: Contradictions in the Proposed Military Tribunals," 25(2) Harvard Journal of Law and Public Policy (2002), pp. 635-652 (637).

7 Supra note 2.

${ }^{8}$ Michael Walzer, Just and Unjust Wars. A Moral Argument with Historical Illustrations, 4th edition, New York: BasicBooks 2006, pp. 24-25.
} 
This apocalyptic vision is all the more frightening because writings and debates on killing in war used to be focused on enemy fighters whereas there are in fact at least four groups of people who can be affected by killing in war. The first and second groups are the fighters on the two adversary sides, not only with regard to their active roles and legitimacy as killers but also as potential victims, in respect of which it should be asked on what legal basis they can be expected, or even obliged, to sacrifice their lives. The third and fourth groups consist of civilians, again on both sides of the military conflict and increasingly more and more afflicted by modern warfare through bombings, distant drone operations, and other hardly controllable military means. As long as the killing of innocent victims on the enemy's side does not cross the threshold to a war crime, criminal law is considered silent. As far as fatalities among one's own population are concerned, these innocent victims, too, may ask why their right to life is considered to be suspended by the mere fact of being at war.

Without ignoring the fact that in all these areas modern international humanitarian law certainly has brought improvements, in particular by penalising and prosecuting war crimes, we are still far from having satisfactory solutions, neither on the international level of the laws of war nor on the national level of constitutional guarantees and criminal justifications and sanctions. Although I cannot here provide a complete solution, I will propose a first step. Instead of simply taking killing in war to be a matter of course, we should pose this question: why should killing in war-as long as it is not considered a war crime-be accepted rather than — as any homicide—prohibited?

With this question in mind, I will argue against the common assumption that in times of war everything that is not expressly forbidden is permitted. I would like to make clear from the outset, however, that I am not doing this in order to impair the situation of soldiers: since they are already exposed to fatal dangers, they shall not and should not be further affected by destabilisation of their legal position. ${ }^{9}$ Far from being so unworldly as to think that killing in war should conclusively be denied all legitimacy, I rather strive for a more fundamental foundation and clearer limitations upon it. In these terms, my main addressees are not the soldiers in the field but legislators and, as their theoretical masterminds, lawyers and political philosophers. They should feel challenged to develop a more solid foundation both for the purposes of preventing abuses and excesses of apparent privileges of war, and for providing military decision makers and actors greater legal certainty. Thus, rather than dwelling on the moral level of the "just war" tradition, which has already been extensively discussed in the literature, my focus here is more on the legal privilege of killing in warwithout thereby ignoring that legitimacy may have its ultimate roots in morality.

This search for legitimacy in killing in war shall be pursued in four steps: First, I will ask whether and why killing in war, as long as it does not cross the threshold to a war crime, shall stay outside the rubric of criminal law (Sect. 2). After not having found a satisfactory answer, I will then ask whether and to what degree constitutional law could provide empowerments and restrictions to killing in war (Sect. 3). As neither framework provides full answers, I shall finally examine, as a last refuge, whether permission can be found through international law (Sect. 4) with particular attention to state sovereignty (Sect. 5). Even on this level, however, killing in war has not yet found convincing legitimisation, thus leaving further challenges to be addressed (Sect. 6).

\footnotetext{
9 As it was suspected in reactions to my newspaper article: Albin Eser, "Dürfen Soldaten überhaupt töten?", Frankfurter Allgemeine Zeitung, December 27, 2011.
} 


\section{Criminal Law Defences?}

If one does not want to accept the factual unavoidability of war-related fatalities as normative legitimisation without further ado, the question arises how and why deadly military actions can be considered exempt from the ordinary criminal law prohibition of homicide. When I searched for answers in German textbooks and commentaries of criminal law, I found hardly any explicit statements, the reason probably being that the principal legitimacy of killing in war seems to be granted as a matter of course. ${ }^{10}$ But, even if so considered, does this discharge the burden of having to provide any rationale? This question should also be put to American textbooks on criminal law; but there, too, as far as I was able to explore, express explanations of killing in war as being legitimate cannot be found either. ${ }^{11}$ Even where issues of killing in war are addressed, the answers are hardly convincing. This is true both for more general arguments exempting killing in war from criminal law and for special justifications.

The easiest way for many scholars seems to be simply to assert that permission to kill in times of war is granted because military actions against enemies are not covered by the crime of homicide. ${ }^{12}$ But why not? If "homicide" means killing a human being-and it does unless "enemy" is excluded from this wording - the killing of an enemy could be denied the character of homicide only if an enemy was derogated the status of a human being. Whilst this may have been feasible prior to the recognition of human rights, it is certainly unacceptable nowadays. ${ }^{13}$ And, even if one assumed a silent exemption of enemies from the definition of homicide, many unanswered questions remain: How is this exemption to be explained? By the mere fact of being at war? Does this mean any war or only legitimate wars? When may war be considered legitimate? Furthermore, even if an exemption from homicide appeared acceptable with regard to combatants, could this exemption also be extended to innocent civilians? The widespread silence on these questions speaks for itself. For as long as exemptions from the definition of "homicide" are not made expressly for killing in war, it is unclear whether they can be assumed at all, and

${ }^{10}$ Albin Eser, „Rechtmäßige Tötung im Krieg: zur Fragwürdigkeit eines Tabus“, in: Dieter Dölling et al. (eds.), Verbrechen-Strafe-Resozialisierung, Berlin: Walter de Gruyter 2010, pp. 461-480 (463), available at: www.freidok.uni-freiburg.de/volltexte/9710.

11 In no recent editions of American criminal textbooks have I found references to military attacks or other issues of killing in war. This even applies to the comparatively comprehensive treatment of criminal law defences by Joshua Dressler, Understanding Criminal Law, 6th edition, New Providence, NJ: LexisNexis 2012, as well as to Fletcher who, though rather in depth arguing on killing in war, apparently sees no need to explicitly justify that combatants "cannot be tried for acts of violence that are normal and standard in fighting war" (supra note 6), p. 639; and even where Fletcher is trying to legitimate ius ad bellum and in particular killing of civilians, as in: "Is Justice Relevant for the Law of War?," 40(3) Israel Law Review (2007), pp. 684-700, without further reasoning, he considers commands to strike enemy troops as "presumptively legitimate" (689).

12 Cf., e.g., Gerhard Werle, and Florian Jessberger, Principles of International Criminal Law, 3rd ed. Oxford: Oxford University Press 2014, p. 392.

13 This change to no longer consider an enemy to be an outlaw was pronounced by the U.S. Supreme Court in Johnson v. Eisentrager, 339 U.S. pp. 763, 768-769 (1950) in stating: "Modern American law has come a long way since the time when outbreak of war made every enemy national an outlaw, subject to both public and private slaughter, cruelty and plunder." By the Court continuing, however, that "even by the most magnanimous view, our law does not abolish inherent distinctions recognized throughout the civilized world between citizens and aliens, nor between aliens of friendly and of enemy allegiance," it becomes doubtful whether enemy combatants and civilians have reached equal respect of their right to life. To the different position of the German constitutional court, see infra in and to note 30 . 
if so why. Nor is it sufficiently clear who should lose criminal protection by such exemptions. Is it only adversary combatants or also civilians, and under what conditions?

This attempt to silently exclude killing in war from the crime of homicide cannot promise better success by resorting to the notion of "social adequacy." According to the theory of "Sozialadäquanz" (as it is used in the German criminal jurisprudence to narrow overly broad crime definitions), ${ }^{14}$ all activities that remain within the framework of the traditional socio-ethical order of social life shall not be considered to be encompassed by the crime's defintion even if they could be subsumed under the wording of the criminal offence. Whilst this interpretative restriction may be feasible for excluding minor wrongdoings, such as everyday insults, from criminal law, it appears abhorrent to characterise killing in war as "socially adequate" and, thus, not covered by the crime of homicide. ${ }^{15}$ Furthermore, from a socio-psychological viewpoint, to refer to the killing of human beings, even if enemies, as "socially adequate" can create the impression of trivialisation; this becomes the more repugnant the more one moves from the direct confrontation of combatants to the so-called "collateral" killing of innocent civilians. For the sake of moral consciousness, "the soldier should know that he is killing", thereby "remaining aware that there are grave and painful actions at stake which require special justification." 16

As soon as a special justification is required, ${ }^{17}$ however, the question of whether killing in war is criminal or not punishable is no longer a matter to be dealt with on the level of the definition of "homicide" but rather concerns the stage of the possible exclusion of criminal responsibility of a deadly act that, as such, fulfills the definitional elements of homicide. ${ }^{18}$ Although both paths-i.e., the exemption of killing in war from the criminal definition of "homicide" or its justification or excuse-lead to the same result (impunity), the underlying distinction is still of high moral and social-psychological significance: when killing is exempt from the definition of "homicide," victims are fundamentally deprived of criminal protection, if not even denied their personhood. If instead we require a justification for killing in war, the message is that even in war human beings are under the protection of the criminal law. ${ }^{19}$ Thus, their killing constitutes homicide which, in order to be lawful, requires justification. This requirement, though also opening the door to finally let soldiers go unpunished, is nevertheless preferable to excluding killing in war from the definition of

\footnotetext{
${ }^{14}$ For a critical survey, see Albin Eser, ,'Sozialadäquanz': eine überflüssige oder unverzichtbare Rechtsfigur?“, in: Bernd Schünemann et al. (eds.) Festschrift für Claus Roxin zum 70. Geburtstag. Berlin/New York: Walter de Gruyter 2001, pp. 199-212, available at: www.freidok.uni-freiburg.de/volltexte/9736.

15 As it was most prominently suggested by Hans Welzel during World War II (afterwards a leading figure in the German criminal law community). See Eser (supra note 10), p. 474.

16 As stated by Hellmuth Mayer, Strafrecht. Allgemeiner Teil, Stuttgart: Kohlhammer 1953, p. 107, therewith moving away from his former support of the "social adequacy" theory (1938), without disclosing, however, his remarkable change of mind.

17 As it is the growing opinion in German case-law and doctrine; see Eser (supra note 10), p. 475.

18 As the three-stage distinction alluded to here is still not so common in Anglo-American criminal doctrine, a brief explanation seems appropriate: required on stage (1) is the fulfilment of the definitional elements of the offence (as in the case of homicide the intentional killing of a human being; in German called "Tatbestandsmässigkeit"), that, on stage (2), principally leads to the wrongfulness of the act (Rechtswidrigkeit) unless excluded by a justification, and, on stage (3), requires the blameworthiness of the actor (Schuld) which may be excluded by an excuse. For further details, see Albin Eser, "Justification and Excuse: A Key Issue in the Concept of Crime," in: Albin Eser, and George P. Fletcher (eds.), Justification and Excuse. Comparative Perspectives, volume 1, Dobbs Ferry/New York 1987, pp. 17-85 (61), available at: www.freidok.uni-freiburg.de/volltexte/3906.
}

${ }^{19}$ Cf. supra to notes 12 and 13 . 
"homicide": first, because by considering any voluntary killing of a human being as fulfilling the definitional elements of "homicide," victims of war-on whatever side and in whatever role, as combatants or civilians-are not disenfranchised from the general protection of the criminal law; second, by requiring a justification, reasons must be given for why and under what conditions human life may be sacrificed during war.

Before being content with the common answer that it is simply the "law of war" that renders the justification, thus escaping the strict requirements of criminal law by simply jumping to the political softness of international law, it seems appropriate first to clarify whether and to what degree we might find grounds for excluding killing in war from criminal responsibility within the rubric of criminal law itself. To anticipate the answer, there is not much to expect from "classical" justifications in criminal law. ${ }^{20}$

This finding already applies to self-defence. Although the underlying defence aspect is not to be underestimated for the legitimisation of war, self-defence and defence of others, already by their very nature and traditional conception, are aimed at the defence of individual legal goods rather than at the protection of state interests. Therefore, even within the framework of a defensive war, killing human beings cannot simply be justified as classical acts of self-defence. This is all the more true in the case of an aggressive war, even if it is pursued for understandable reasons, such as a humanitarian intervention. There may be room for individual self-defence in war insofar as, in close combat, a soldier forestalls an attack already directed to him with a quicker defensive shot. Yet even in such a case, the unlawfulness of the adversary's attack, required for self-defence or defence of others, can be missing. The case for "classical" self-defence of a combatant-or defence of a comrade-is even harder to make when force is being used pre-emptively against a not yet attacking enemy or an already fleeing one. ${ }^{21}$

This unavailability of self-defence as a justification for killing in war becomes even more evident with regards to the killing of innocent civilians. Downplaying their fatalities as "collateral damage" must not cloud our judgement that self-defence grants justification only against the attackers and not against mere bystanders as civilians normally must be considered. When they are killed, we must look elsewhere for justification.

Perhaps one might think here of "necessity", in terms of being the lesser evil by killing enemies for saving higher humanitarian values, or sacrificing civilian fatalities as an unavoidable co-product of military actions, being the lesser evil. Insofar as necessity is taken into consideration at all, ${ }^{22}$ however, it can hardly provide a justification because, if nothing else, it would be undermined by the imponderability of life against life. And even if-instead of "justifying necessity"-one might think of "excusing necessity", as necessity is divided in the German Penal Code $(\S \S 34,35)$, in terms of exculpating the actor merely for personal reasons whilst not justifying his act of killing, ${ }^{23}$ not much is

\footnotetext{
${ }^{20}$ Albin Eser, „Tötung im Krieg: Rückfragen an das Staats-und Völkerrecht“, in: Ivo Appel et al. (eds.), Öffentliches Recht im offenen Staat, Berlin: Duncker \& Humblot 2011, pp. 665-687 (667), available at: www.freidok.uni-freiburg.de/volltexte/9714.

21 If this position appears too strict, it should be kept in mind that on the level of criminal law defences at stake here one should not too easily escape the requirements of self-defence as it may be done from a moral point of view - as, for instance, by softening the immediacy requirement in terms of being at war.

22 Cf. Antonio Cassese, International Criminal Law, 3rd edition, Oxford: Oxford University Press 2013, p. 214 with reference to ICTY in Prosecutor v. Oric, IT-03-68-T, Oral Decision 8 June 2005, pp. 9027-9033.

23 As to this differentiation, which resembles the common law distinction between necessity and duress, cf. Kai Ambos, Treatise on International Criminal Law. Foundations and General Part, volume 1. Oxford: Oxford University Press 2013, p. 342.
} 
really won. In particular, not much is won for soldiers who are expected to bear fatal hazards that are not to be simply averted by killing non-combatants. Furthermore, soldiers would certainly be dissatisfied in trading their military actions for a mere excuse rather than for a justification.

If necessity is to have any justifying impact at all, it might be imaginable in the form of so-called "defensive necessity", as in the shooting down of a hijacked airplane that could be used as a weapon against innocent people, thus rescuing those on the ground by sacrificing those in the air because of their being doomed anyway. ${ }^{24}$ But, even if such a fatal action could be legitimised as a sacrifice for the sake of saving others, ${ }^{25}$ analogous to the killing of innocent civilians in war, it is highly doubtful whether by doing so one is still moving within the realm of criminal law defences. By contrast to traditional cases of selfdefence and necessity that are designed for actions between private citizens, both orders to shoot down a hijacked airplane and the killing of innocent civilians as "collateral damage" of a military operation are interventions attributable to the state and, thus, are a kind of state action. Due to this state-related character, however, fatal military operations cannot be fully accounted for within the rubric of criminal law but, as deadly interventions performed under state command, they may require constitutional legitimisation. ${ }^{26}$

The criminal law's transcending feature becomes still more apparent if homicide is declared "justifiable" when committed "in the proper performance of a legal duty"according to the U.S. Manual for Courts Martial-as is the case of "killing an enemy in battle" ${ }^{27}$ Although legal duties, privileges of officials, as well as military orders can be integrated into the rubric of criminal law by employing them as defences, ${ }^{28}$ they have their foundation in public law and thus may be governed by, and subject to, the requirements of domestic constitutional and even international law.

\section{Constitutional Empowerments?}

As already indicated, the mainstream opinion would directly resort to international law by justifying killing in war with reference to the laws of war. ${ }^{29}$ Before examining this common shortcut, however, it appears necessary first to ask whether there might be both domestic empowerments and restrictions to killing in war. Until recently, this question was hardly asked in Germany, and it would not be surprising if the same were true elsewhere. The reason for not scrutinising killing in war from a constitutional perspective seems to be

\footnotetext{
${ }^{24}$ Cf., e.g., Hans-Joachim Hirsch, „Defensiver Notstand gegenüber ohnehin Verlorenen“, in: Michael Hettinger et al. (eds.), Festschrift für Wilfried Küper, Heidelberg: C.F. Müller 2007, pp. 149-172 (153).

25 Contrary to the position taken by the German Federal Constitutional Court in BVerfGE (Entscheidungen des Bundesverfassungsgerichts) 115 (2006), pp. 118, 154.; cf. infra to note 32.

26 Eser (supra note 20), pp. 677.

27 U.S. Manual for Courts Martial (1951), § 197(b) according to which "homicide committed in the proper performance of a legal duty is justifiable," interestingly, though, without explicitly mentioning killing of innocent citizens. As to "military orders," cf. Paul H. Robinson, Criminal Law Defenses, volume 2, St. Paul, Minn: West Publishing Co. 2014, § 148.

28 As categorised in terms of a justification by Robinson (ibid.) and as-regarding German criminal jurisprudence_-similarly indicated by Oberlandesgericht Kiel, 2 Süddeutsche Juristenzeitung (SJZ) 1947, pp. 323, 329. For further references, cf. Eser (supra note 20), p. 670.

29 Cf. infra Sect. 4.
} 
unawareness of the fact that killing in war, if authorised by the respective state, rather than being merely an individual act of the soldier, is ultimately attributable to the state and, thus, must be reconcilable with its constitutional requirements and guarantees.

Still, at this national level (as it will be argued from a German perspective, but as it may also be similarly the case in other legal orders), there are two constitutionally significant hurdles that must be overcome to legitimise killing in war.

First, start with the inviolability of human dignity (Art. 1 German Basic Law) and the right to life [Art. 2(2) German Basic Law]; these are human rights and freedoms that are guaranteed to every human being. Thus, they are irrespective of citizenship or any other status, as well as being irrespective of the effects of state activity occurring abroad. ${ }^{30}$ Accordingly, participants in a war on whatever side, too, may claim equal constitutional respect and protection.

Consequently, any deadly military action induced by, and thus attributable to, the respective state- on whatever side-would be unlawful if it was to be considered a violation of human dignity and therefore irreconcilable with the Constitution. This seemingly total blocking of killing in war, however, is overcome by considering human dignity merely as the basis of the protection of life, whereas acknowledging that the exact extent of human dignity would need to be determined according to the life's guarantee in Art. 2(2), sentence 1, of the German Basic Law. ${ }^{31}$ Furthermore, killing as such shall not be considered a violation of dignity as long as it is not performed in a degrading manner. ${ }^{32}$ Since a degrading manner can only be assumed if the killing amounts to a war crime, human dignity appears not to be touched by "normal" military fatalities.

Second, this seems to be different with regards to the right to life, since a violation of this right can hardly be denied when a human being is killed. However, as this right is not granted in absolute terms but may be "interfered with [only] pursuant to a law" [Art. 2(2), sentence 2, German Basic Law], the right to life is not necessarily inviable. Yet, as invasions into this right are permitted "only" by virtue of a statute ("auf Grund eines Gesetzes"), the question arises where such a legal license to kill could be found-and, as an additional requirement, in the form of a "statute". Given that the Basic Law does not speak of "Recht" (in terms of law) but of "Gesetz", a written form is normally required. ${ }^{33}$ As no general exception is made for killing in war, its legitimacy finally depends on the norms and circumstances from which the permission of potentially fatal encroachments on the guarantee of life could be derived. There are mainly four groups of potential victims of war to which special attention must be paid.

1. Regarding enemy combatants as the group most directly affected, the license to kill them appears so obvious that even larger commentaries and textbooks on the German

\footnotetext{
30 BVerfGE 6 (1957), pp. 290, 295.

31 As, in principle, already stated in BVerfGE 88 (1993), pp. 203, 251. Though being aware that the extraterritorial protection of human rights is not realised in all states, those states concerned-if hopefully open for further enlightenment on the universal nature of human rights and the responsibility of state power wherever it takes effect—-should be expected to recognise that the right to life is taken seriously as a truly "human" right only if is not merely guaranteed to one's own nationals and/or restricted to state acts on their own territory.

32 According to a landmark decision to the "Luftverkehrssicherungsgesetz" (Air Traffic Protection Act), the German Federal Constitutional Court would see such an "entwürdigend" degrading case in the shooting down of a hijacked airplane because there the passengers and crew members, while finding themselves in a hopeless and inescapable situation, would be used as means for rescuing other people and, thus, be "reified": BVerfGE 115 (2006), pp. 118, 154.
}

33 Cf. BVerfGE 40 (1976), pp. 237, 249. 
Basic Law content themselves with cursory remarks, such as "military operation" 34 or "event of war". ${ }^{35}$ Even insofar as we look for explicit references to fatal military actions in written law, doubts remain. This point concerns the assumption that interferences with the right to life of enemy combatants are silently presupposed permissible, or that the license to kill may be implicitly derived from the entirety of the constitutional rules on deployment of the German armed forces. ${ }^{36}$ This reasoning is particularly questionable if based on the common "trump card" provision empowering the Federal Republic to establish and deploy the armed forces (Art. 87a German Basic Law). But since these are merely organisational authorisations, they do not per se grant the power to interfere with human rights beyond those conceded in the respective constitutional provisions. If, thus, the aforementioned constitutional proviso of the statutory requirement for interferences ("Eingriffsvorbehalt") with the right to life is indeed to be taken seriously, instead of being content with rather daring deductions of licenses to kill from administrative-organisational assignments of tasks, then at least from a formal point of view it will not be easy to get around this human right protection without any statutory authorisation. This is true even with regard to enemy combatants and even if substantive grounds for killing may be available (as discussed later). ${ }^{37}$

2. The ground gets still less secure when one moves to "collateral" fatalities among enemy civilians. Not only that with regard to them, too, a formal license to kill would be necessary; it is even more difficult to find substantive reasons for sacrificing innocent people. ${ }^{38}$ Civilians, still less than combatants, cannot be considered to be principally exempted from the constitutional guarantee of the right to life; thus, to be-voluntarily or accidentally — sent to death, a statutory legitimisation is required. This cannot simply be found in the fact that the killing of innocent civilians is not a war crime as such, but under certain conditions only. ${ }^{39}$ For, contrary to a widespread opinion, it is unfeasible to derive a license to kill simply from the non-existence of a prohibition to kill. Such a conclusion could only be drawn if life was protected only insofar as its destruction is explicitly prohibited-an assumption obviously in fundamental contradiction to the primary right to life. ${ }^{40}$

3. Still more difficult to find is a statutory legitimisation for war fatalities among one's own citizens, be they combatants or civilians. As for one's own combatants, the focal point here is no longer the active license to kill but rather the passive toleration of them being killed. This is not to ignore that, as in the case of so-called "friendly fire," active

\footnotetext{
34 As, e.g., Udo di Fabio in the leading commentary of the German Basic Law by Theodor Maunz et al. (eds.), Grundgesetz, volume I, München: C.H. Beck 2009, p. 40.

35 Cf., e.g., Philip Kunig, in: Ingo von Münch, and Philip Kunig (eds.), Grundgesetzkommentar, 5th ed. München: C.H. Beck 2000, Art. 2 margin no. 44; though in the revised 6th edition of 2012 Kunig describes military fatalities as "limited by international law", by speaking merely of "limitation," he implicitly presupposes that killing is principally permitted.

36 For more details, see Eser (supra note 20), p. 673.

$37 \mathrm{Cf}$. infra VI. In this respect, it is all the better, of course, if national law requires parliamentary authorisation of military force with potential fatalities if a conflict reaches a certain level, as seems to be the case in U.S. law (though doubts remain on how strictly such requirements are complied with in practice).

38 In order to avoid misunderstanding at this point, it should be remembered that the question at stake here is not whether there may be (justificatory) "lesser evil" arguments but whether, or on what legal basis, sacrificing innocent life can be reconciled with the constitutional right to life.

39 Art. 8(2)(b)(i) and (iv) Rome Statute.

40 Eser (supra note 10), p. 469.
} 
killing can also occur between one's own comrades for which a license to kill is probably not provided. ${ }^{41}$ However, as less reflected upon, attention must also be given to the passive side of the coin by asking whether and to what degree a state, by engaging in a war, is empowered to expose its citizens to the risk of being killed at enemy hands.

As far as soldiers - or similarly conscripted people - are concerned, the preparedness and professional obligation to take fatal risks appears indispensable. To treat this as a matter of course, however, as is traditionally done, is increasingly questioned in Germany. Yet this debate centres not on the fundamental question but instead remains focused on the question of restrictions, thus presupposing that killing in war is legitimised in principle. According to the general theory of the state, and of law, regarding the case of national defence, a citizen, due to his ligation as member of the public community ("Gemeinschaftsgebundenheit"), may be expected to risk his life. Less easy, however, is the question of whether and to what degree such a principal obligation can be imposed without reservation and limitation. At any rate, we can certainly demand of someone to risk his life when armed operations are within the constitutional framework of national defence. However, even with that proviso the government can hardly ask for more than an engagement by which life is (merely) put in danger, but not to be exposed to the foreseeably fatal sacrifice of one's life as would be the case when consciously sending soldiers to their deaths. Although soldiers can still be expected to give a minimum of solidarity, it will not be easy to determine this minimum in substance, in particular if a line has to be be drawn between what would still be a reasonable assumption of risk and what should be considered an excessive order of senseless perseverance ("Durchhaltebefehl"). ${ }^{42}$

4. Still much more difficult to constitutionally legitimise are fatal sacrifices among one's own civilian population. At first glance, the loss of life by being bombed by enemy forces seems to pose the same questions as in the case of passengers of a hijacked airplane that is shot down to prevent even greater evil. In both cases, the victims are objects of other ends: national defence or the protection of people on the ground. There is a significant difference to be noted, though: in the case of shooting down a hijacked airplane, by weighing life (of the passengers and the crew in the airplane) against life (of threatened people on Earth), there is a concrete rescue conflict at stake. In the case of war, the population threatened by enemy attacks must sacrifice their lives for the more general goal of national defence. In the eyes of the German Federal Constitutional Court, the state is deemed to be entitled to request such a sacrifice from its citizens. This is based on the assumption that the Constitution, by empowering the state to provide national defence through the military, is indicating that if the employment of weapons against an enemy is in accordance with international law, repercussions on its own population are not necessarily outlawed by the protective scope of the right to life. ${ }^{43}$ Such a "quasi-definitional restriction of the right of life" 44 towards innocent civilians, however, is even less convincing than with regard to

\footnotetext{
41 Though this raises questions that are not far away from the American discussion on the deployment of drones, the focus here shall remain on killing in war.

42 For more, see Eser (supra note 20), p. 675.

43 BVerfGE 77 (1988), pp. 170, 221.

44 As it was, not without critical undertone, concluded from the constitutional court's decision by Michael Sachs, in: Klaus Stern (ed.), Das Staatsrecht der Bundesrepublik Deutschland, volume III/2, München: C.H. Beck 1994, p. 586.
} 
conscripted soldiers. If the requirement of a statute for interfering with the right to life, as stipulated in Art. 2(2), sentence 2, German Basic Law and perhaps in other constitutions, shall not be left completely idle, a general reference to national defence cannot suffice. Even if the expansion of a civilian duty to sacrifice oneself up to the loss of life may not be illegitimate in principle, that can hardly be assumed without certain restrictive conditions. $^{45}$

\section{International Law as Last Resort?}

Since a positive license to kill in war can be found neither in criminal nor in constitutional law, ${ }^{46}$ the leap to international law is increasingly finding followers. This argument can be found in mainly three different manners: first, by considering national law (including constitutional law) superimposed by international law of war; second-less specificallyby simply referring to international law as the highest instance for the evaluation of killing in war; and finally-in its most oversimplified manner-by suggesting that in the case of war everything that is not forbidden is permitted. ${ }^{47}$

The most realistic approach is certainly the last one, as it seems to be the secret mainstream opinion in theory and practice, as recently also alluded to in the nolle prosequi order of the German Chief Federal Prosecutor in the hotly debated Kundus case. ${ }^{48}$ In fact, it is also the most honest approach, as it indirectly concedes that under international law we also lack an explicit positive justification of killing in war. This lack of an express authorisation is likely to be overcome by referring to Art. 22 of The Hague "Regulations Respecting the Laws and Customs of War on Land" of 1907, according to which "the right of belligerents to adopt means of injuring the enemy is not unlimited." By merely speaking of limits to possible means of injuring the enemy, however, The Hague "War on Land Order" obviously presupposes a license to injure, virtually up to the level of killing people. This is implicitly also confirmed by the fact that Art. 23 of The Hague "War on Land Order" - as various other instruments before or since ${ }^{49}$ — confines itself to partial prohibitions of certain particularly inhumane means of killing, and forbids excesses against the civilian population $^{50}$ — without, however, outlawing killing as such and, thus, in principle presupposing it is lawful. But insofar as they do not contain an explicit justification of killing in war either, the question of whether it is unlawful or punishable is left open. By then employing the reverse conclusion that what is not forbidden is considered permitted, the international law on war can easily be interpreted as permitting any military operations and fatalities as long as they are not prohibited. With regards to war, this means that causing death is not punishable as long as it does not cross the high threshold of an

\footnotetext{
45 Eser (supra note 20), p. 677.

46 Adalbert Podlech, in: Erhard Denninger (ed.), Kommentar zum Grundgesetz für die Bundesrepublik Deutschland, Neuwied: Luchterhand 1984, Art. 2 section 2 margin no. 26.

47 For an overview on sources, cf. Eser (supra note 20), p. 678.

48 In which-beside some Taliban combatants-dozens of civilians were killed by a misguided NATO air attack: cf. Einstellungsverfügung des Generalbundesanwalts im Ermittlungsverfahren gegen Oberst Klein3 BJs 6/10-4 of April 19, 2010.

49 As, e.g., by the Lieber Code.

50 As it was later on stipulated in the Additional Protocols to the Geneva Conventions.
} 
international crime. ${ }^{51}$ But, even though one admits that below this threshold there are certain means and excesses of killing in war which, though not punishable, are at least interdicted by humanitarian international law, there still remains a tremendously large area for killing in war that is not considered criminal homicide, let alone finally punishable.

Beyond the factual drama of countless human sacrifices going unpunished due to the assumption that what is not forbidden is permitted, this claim is also untenable from a normative perspective. In particular, it is hardly persuasive from a human rights conceptual understanding of freedom and prohibition. Although it may seem that it is to prize liberty to consider that what is not forbidden is allowed, such a maxim is feasible only where, by refraining from a prohibition, a right or freedom that already exists shall not be restricted. Thus, with regard to killing other human beings, the maxim of refraining from restricting what is a legitimate freedom could only come into question if killing were part of the principally unlimited freedom of personal development and activity. ${ }^{52}$ Such a far-reaching primary freedom to kill, however, would hardly be reconcilable with modern general principles of law, particularly not with modern human rights and their foremost right to life. Therefore, it is not the right to life but its violation that requires justification. In sum, given that killing human beings is prima facie prohibited and, thereby, the exercise of personal freedom with deadly means limited from the very outset, killing in war cannot simply be considered legitimised by the absence of an explicit prohibition of killing in war. $^{53}$

\section{State Sovereignty as the Crucial Key?}

If one wants to explore on what grounds it could be explained that the martial license to kill is widely assumed as a matter of course, the most promising way to do so is to look into the changing history of modern international law and the concept of sovereignty.

As can only roughly be outlined here, ${ }^{54}$ until the beginning of modern international law in the 16th century, in particular connected with the work of Hugo Grotius, the prevailing theory, developed from medieval theology, was that of the "just war" tradition. Killing of an enemy was permitted only if the war was based on a just cause, performed with a righteous intention, and authorised by a legitimate ruler. Of course, there is no doubt that the implicit requirement of "justice" is difficult to verify, and thus easily claimed by both sides. Nevertheless, in principle, killing in war could be legitimised in each case from one side only.

This shield against unjustified wars with inevitably deadly consequences, however, has been more and more undermined. This in particular resulted from the alleged "indifference" of international law regarding the law of war that, in connection with the concept of the "mutually just war", finally led to the ius ad bellum in terms of a free "right to war" based on the sovereign self-determination of states. Consequently, every warring state could consider itself fighting a bellum iustum. ${ }^{55}$ In this concept of the "self-righteous" war,

\footnotetext{
51 Issacharoff, and Pildes (supra note 5), p. 1545.

52 As it was assumed by Thomas Hobbes, The Leviathan, ed. by Richard Tuck, Cambridge University Press 1991, Chap. XXI, p. 149, Chap. XXX, p. 244.

53 Cf. also Eser (supra note 10), p. 469.

54 For more, see Eser (supra note 20), p. 680.

55 Paul Guggenheim, Lehrbuch des Völkerrechts, Band II, Basel: Verlag für Recht und Gesellschaft 1951, p. 591 with further references.
} 
the only issue left to be solved was whether and how warfare was to subject itself to certain restrictions regarding its conduct and means. Although as per the ensuing ius in bello in terms of "law in war" (as evolving from The Hague "War on Land Orders") the traditional right to war was not affected in principle by the further development of international humanitarian law, the door was at least opened for the prosecution of particularly grievous violations of protective regulations as war crimes.

Another development in international law took a rather ambivalent course, on the one hand, by restricting causes for military fatalities and, on the other, by expanding them. In the restrictive direction, the free right to warfare was more and more limited by finally subjecting it to an international ban on the use of force. ${ }^{56}$ This prohibition of the use of force is not without exceptions though. Nevertheless, by allowing the use of force on three grounds only-(1) for exercising a state's "inherent right of individual or collective selfdefence", (2) in case of consent of the state concerned, or (3) due to the decision by an authorised international organisation ${ }^{57}$ - , resort to force requires justification.

Although this anti-war trend of modern humanitarian international law is certainly welcome, it can lead to unwanted side effects. The more humanitarian interventions are demanded for preventing grievous violations of human rights, the more the gates open for the employment of military force-with corresponding risks for life and limb both for combatants and civilians. ${ }^{58}$

Nevertheless, however narrow or wide the exceptions to the prohibition of force may prove to be, significant progress has been made. While in times of prevailing "indifference" of international law regarding the right to resort to war, the state was free to decide on the use of military-and thus inevitably also deadly-force. By contrast, this is nowadays permitted in justified exceptions only. In addition, this not only applies to "war" in narrower terms but also to any "armed conflict". 59 Accordingly, we have thereby witnessed a development from a "self-righteous law of war" to a "law of international conflicts which requires justification." 60

When in spite of this progress the practice of war continues under the motto "martial license to kill as long as not explicitly forbidden", this may be explained by reference to the sovereign aspect of an immanent power to wage war. If, as it can be read again and again, the right to kill people is seen as "implied" in the right to war, or as "inherent" in armed conflict, it seems reasonable to understand killing as a downright self-evident means of war. To accept this as a "matter of course", however, would be feasible only if the permissibility of killing in war could simply be derived from the absence of an explicit prohibition. This again would presuppose that, on the level of international law too, in war life is fundamentally without right and, thus, can gain legal protection only if and when its destruction is prohibited. It remains entirely obscure to me how such a basic understanding of life as lacking any legal protection could be reconciled with human rights guaranteesunless in case of war human life would be from the very outset exempted from human rights protection as it seems to be insinuated by provisions enacting the right to life in

\footnotetext{
56 Articles 2(4), 40, and 51 United Nations Charter.

57 For details to the exceptions from the prohibition of force, see Wolff Heintschel von Heinegg in Knut Ipsen, Völkerrecht, 6th edition, München: C.H. Beck 2014, p. 1077.

58 Gilles Andréani, and Pierre Hassner (eds.), Justifying War? From Humanitarian Intervention to Counterterrorism, New York: Palgrave, 2008.

59 Ipsen (supra note 57), p. 1196.

${ }^{60}$ Ibid., p. 1195.
} 
international conventions. ${ }^{61}$ Since such pre-exemptions from protection can hardly have been intended, we would need special empowerments for the destruction of human life also at the international level. Such positive authorisations, however, cannot simply be derivedindirectly-from prohibitions of certain means of killing and excesses.

If one looks for reasons to explain why the traditional doctrine and practice is satisfied with this lack of an explicit authorization for killing in war, one could perhaps resort to customary international law conceptions such as the perception of war as a "measure of legal protection" in terms of a reaction to a wrong inflicted to the state. ${ }^{62}$ This is unconvincing, though, insofar as this sanction need not be appropriate to the wrong suffered. ${ }^{63} \mathrm{~A}$ further question therefore is on what ultimate reason one may base the facticity of war-in terms of a custom that would not require explicit legitimacy. Here again we must go back to the doctrine of sovereignty predominantly underlying the right to warfare. If sovereignty-on the one hand—not only serves as protection against interventions by other states but-on the other- is also understood as a right to go to war for pursuing one's own interests, ${ }^{64}$ it appears conclusive to describe war as "a right inherent in sovereignty itself" 65 and thus to consider the state free in choosing its military means as long as the state has not subjected itself to certain restrictions by way of international instruments.

Yet, is this a sustainable model? Quite apart from the fact that the concept of sovereignty has no straight line of development, ${ }^{66}$ doubts arise in two-somehow opposingrespects. First, I consider it basically misguided to see human life subjected to the killing power of a sovereign as long as killing is not explicitly forbidden. If this were true, in case of war, human life would in principle be a kind of outlaw, only exceptionally protected, and even then merely against certain means of killing or only when it is disproportionate. This position is to be countered by the fact that the sovereignty of states is not only restricted by explicit prohibitions to kill, as those introduced in The Hague and Geneva Conventions, or in the crime catalogues of international criminal justice, but also by virtue of the international recognition of human rights. Second, as long as the right to life, whether of civilians or combatants, is not exempted from this guarantee-and such an exemption is not apparent in any of the relevant human rights conventions, ${ }^{67}$ there is no reason to assume that the sovereign has a license to kill as a "matter of course," obtainable by the mere fact of going to, and calling it, "war"-without needing any further justification.

\footnotetext{
${ }^{61}$ This, in particular, even applies to article 15 section 2 of the European Convention on Human Rights, according to which derogations from the right to life (article 2) may (only) be made "in respect of death resulting from lawful acts of war"; cf. Eser (supra note 10), p. 468.

62 Paul Guggenheim, Traité de Droit international public, Tome II, Genève: Librairie de l’Université 1954, p. 93.

${ }^{63}$ Ibid.

${ }^{64}$ Anthony Clark Arend, and Robert J. Beck, International law and the use of force, London: Routledge, 1993, p. 16.

65 Yoram Dinstein, War, Aggression and Self-Defense, Cambridge: Cambridge University Press 1988, p. 72.

${ }^{66}$ Stefan Oeter, „Souveränität—ein überholtes Konzept?“, in: Hans-Joachim Cremer et al. (eds.), Tradition und Weltoffenheit des Rechts, Berlin: Springer 2002, pp. 259, 261.

${ }^{67}$ See, in particular, Christian Tomuschat, "Töten im Krieg", Frankfurter Allgemeine Zeitung, April 14, 2012, who, in an obvious though not explicit reaction to my Frankfurter Allgemeine Zeitung article (supra note 9), had to concede that "there is no international legal instrument, nor the Basic Law, that would allow killing in war expressly".
} 


\section{Killing in War in Need of Legitimacy!}

In criticising the lack of a positive justification for killing in war, I am not so unworldly as to think that killing in war could not be justifiable in principle. On the contrary, in the same way as a private citizen has the right to resort to-if necessary, even deadly-self-defence against an unlawful attacker, a country under attack must have the same right, including the military personnel employed for its defence. However, it is necessary that licenses to kill are positively authorized and circumscribed in their requirements and limits.

What is at issue thus is to put an end to the "matter of course" attitude according to which in martial operations everything that is not explicitly forbidden shall be allowedwithout taking notice of constitutional guarantees and international human rights to life. Even if certain means of killing may be forbidden by international law and, even if the civilian population shall be spared disproportionate loss of life, the basic issue still remains unsatisfactory: the fundamental human rights guarantee to life during war. As the protection of this right is encompassed by the general prohibition of homicide, exceptions therefrom require justification that cannot simply be derived from the absence of a prohibition of the prospective military actions.

Instead of giving killing in war principally free reign and merely restricting it by means of punctual prohibitions, and/or by criminalising merely certain military actions, the requirements and limits of lawful killing in war must be determined in a positive way. This would be of particular significance in the following respects.

First, if every human being has the right to life fundamentally protected against homicide, killing requires justification. As this justification cannot be derived from war as such, killing in war must be legitimised for other reasons. This already requires that the goals and interests are determined and weighted for the defence and assertion of which human life may be sacrificed: be it on the enemy's side or regarding the danger to life of one's own combatants. If such an identification and evaluation of the interests at stake were performed in a responsible manner, then-apart from clear cases of defensive force used against an aggressive war waged in violation of the international prohibition of forcemany conflicts undertaken for economic goals or ethnic cleansing would reveal their lack of legitimacy. The same applies to military confrontations that are waged in order to rescue the so-called "national honour." Of course, by requiring greater precision in terms of the reasons for going to war, new discussions of "just war" may arise. ${ }^{68}$ This, however, is inevitable the more the use of force is withdrawn from autocratic state sovereignty and put at the service of humanitarian aims. ${ }^{69}$

Second, if a certain legitimising ground must be given, it will be much easier to determine and describe the requirements and limits of lawful killing. When the permission to kill enemy combatants and to sacrifice one's own cannot simply be derived from state sovereignty, other justifying arguments will be needed. Apparently, paradigms of selfdefence and defence of others, as well as of necessity and lesser evils, are the first candidates to be taken into consideration. Without ignoring that these justifying concepts have

\footnotetext{
${ }^{68}$ Cf. Walzer (supra note 8), Jeff McMahan, Killing in War, Oxford: Oxford University Press 2009, and Eberhard Schockenhoff, „Schutzverantwortung als Interventionsgrund? Die "responsibility to protect” im Rahmen einer Theorie des gerechten Friedens“, in: Björn Burkhardt et al. (eds.), Scripta amicitiae. Freundschaftsgabe für Albin Eser zum 80. Geburtstag, Berlin: Berliner Wissenschafts-Verlag (BWV) 2015, pp. 203-234 (231).

${ }^{69}$ Hereby the doctrine of "just war" may finally lead to a doctrine of "just peace": cf. Schockenhoff, ibid., p. 234 .
} 
primarily been developed in view of individual conflicts, they nevertheless contain criteria relevant for defence in inter-state or group conflicts, and the potential for weighing up the pros and cons of specific military actions, thereby making them useful for determining the requirements and limits of justifiable killing in war. This applies also to the killing of innocent civilians, the justification of which still awaits a satisfying solution. ${ }^{70}$

Third, if legitimised in a positive way, formal prerequisites of the rule of international and constitutional law could be better satisfied. Since, according to the modern prohibition of the use of force military operations require international authorisation, ${ }^{71}$ going to war is no longer within the free will of states. Such an authorisation is easier to evaluate the more clearly its conditions are formulated. And, insofar as constitutional law provides that infringements to the right to life that are attributable to the state presuppose a statutory permission, ${ }^{72}$ a license to kill cannot be derived in a merely negative way from the prohibition of selective modes of killing. Killing as such requires legitimacy in form of a positive and at least quasi-statutory authorisation. ${ }^{73}$

That is all the more necessary the more the notion of "war" becomes blurred and extended to "armed conflicts" that are difficult to define. At first glance, extending the framework of war to these situations appears well-intentioned because it brings non-state combatants under the umbrella of modern humanitarian law. Yet this again loses much of its value if, according to traditional practice, the prohibition on killing in such contexts is simply considered suspended. Should this also apply beyond international wars to noninternational armed conflicts, then "easy" killing does not remain limited to "external" enemies but will increasingly be extended to "internal" adversaries as well. It takes little effort to imagine where this development could lead if the traditional license to kill were to be applied to all of what nowadays is lightly called "war"- such as the "war on terror"or expanded to "targeted killing", "machine wars" with remotely controlled drones, and even to the so-called "enemy criminal law" as it is hotly debated in Germany, Spain, and Latin America. ${ }^{74}$ Such undesirable developments, too, can best be countered by giving the justification of killing in war contours in a positive legal way. ${ }^{75}$

It would not be surprising if these demands gave rise to fears that a country could make itself defenceless if it subjects itself to requirements of legitimacy as long as other countries refrain from undergoing such restrictions. Nor shall we ignore that these reform proposals need further elaboration. In a similar way, however, as the development of humanitarian international law required time and political will, the demythologisation of the martial license to kill needs the courage of individual countries to take the first step, hoping that others will feel motivated to follow.

\footnotetext{
70 Stefan Oeter, „Kampfmittel und Kampfmethoden in bewaffneten Konflikten und ihre Vereinbarkeit mit dem humanitären Völkerrecht“, in: Jana Hasse et al. (eds.), Humanitäres Völkerrecht, Baden-Baden: Nomos 2001, pp. 78-109 (83).

71 Cf. supra note 56.

72 Cf. supra Sect. 3.

73 See Muna A. Yousif, Die extraterritoriale Geltung der Grundrechte bei der Ausübung deutscher Staatsgewalt im Ausland, Frankfurt: Peter Lang 2007, pp. 166, 188, 212.

74 Carlos Gómez-Jara Díez, "Enemy Combatants versus Enemy Criminal Law: An Introduction to the European Debate Regarding Enemy Criminal Law and its Relevance to the Anglo-American Discussion on the Legal Status of Unlawful Enemy Combatants," 11(4) New Criminal Law Review (2008), pp. 529-562, among others. As to my own criticism, see Albin Eser et al. (eds.), Die deutsche Strafrechtswissenschaft vor der Jahrtausendwende, München: C.H.Beck 2000, p. 444.

75 Issacharoff, and Pildes (supra note 5), pp. 1596.
} 
In these terms, like torture and capital punishment were abolished step-by-step (though not completely), utopia is the mother of progress. It is in this spirit that the considerations presented here may stimulate a discussion on what all too long has been treated as a "matter of course". Although killing in war, realistically as well as regrettably, will never be completely stopped, to be considered lawful, its legitimacy must at least be better founded.

Acknowledgements Open access funding provided by Max Planck Society.

Open Access This article is distributed under the terms of the Creative Commons Attribution 4.0 International License (http://creativecommons.org/licenses/by/4.0/), which permits unrestricted use, distribution, and reproduction in any medium, provided you give appropriate credit to the original author(s) and the source, provide a link to the Creative Commons license, and indicate if changes were made. 